\title{
Article
}

\section{De-Powdering Effect of Foundry Sand for Cement Casting}

\author{
Seungyeop Chun ${ }^{1,2}$, Geumyeon Lee ${ }^{1}$, Sujin Kim ${ }^{1}$, Bora Jeong ${ }^{1}$, Jeehoon Shin ${ }^{3} \mathbb{D}$, Inkyung Cho ${ }^{1}$, \\ Hongdae Kim ${ }^{1}$ (D) Heesoo Lee ${ }^{2, *}$ and Taewook Kim ${ }^{1, *(D)}$
}

1 Industrial Environment Green Deal Agency, Korea Institute of Industrial Technology, Ulsan 44413, Korea; jsymen@kitech.re.kr (S.C.); kum0624@kitech.re.kr (G.L.); sujiny@kitech.re.kr (S.K.); bora1106@kitech.re.kr (B.J.); birdman98@kitech.re.kr (I.C.); hdkim@kitech.re.kr (H.K.)

2 Department of Material Science and Engineering, Pusan National University, Busan 46241, Korea

3 Department of Materials Science and Engineering, Korea Advanced Institute of Science and Technology, Daejeon 34141, Korea; jeehoonshin@naver.com

* Correspondence: heesoo@pusan.ac.kr (H.L.); taewook@kitech.re.kr (T.K.)

check for updates

Citation: Chun, S.; Lee, G.; Kim, S.; Jeong, B.; Shin, J.; Cho, I.; Kim, H.; Lee, H.; Kim, T. De-Powdering Effect of Foundry Sand for Cement Casting. Appl. Sci. 2022, 12, 266. https:// doi.org/10.3390/app12010266

Academic Editor: César M.

A. Vasques

Received: 17 November 2021

Accepted: 20 December 2021

Published: 28 December 2021

Publisher's Note: MDPI stays neutral with regard to jurisdictional claims in published maps and institutional affiliations.

Copyright: (c) 2021 by the authors Licensee MDPI, Basel, Switzerland. This article is an open access article distributed under the terms and conditions of the Creative Commons Attribution (CC BY) license (https:// creativecommons.org/licenses/by/ $4.0 /)$.

\begin{abstract}
With the development of the powder bed 3D printing process, sand casting can be performed with methods that are more advanced than the traditional ones, thus enabling new research on applied materials. When sand is 3D-printed with cement as a binder, its casting performance is improved and sufficient thermal stability of conventional organic and inorganic binders is ensured. In this study, to ensure high resolution and strength in a physical and simple mixture of cement and sand, the compatibility for casting was confirmed using submicron-level cement with ingredients and sizes similar to commercial sand, which is uniformly controlled at $4 \mu \mathrm{m}$, instead of conventional sand. To enable quick 3D printing, calcium aluminate cement, which has quick binding properties, was used for high-temperature casting. The strength up to $6 \mathrm{~h}$ after hydration was compared to determine the curing rate of silica, mullite, and alumina sand containing cement components. By investigating the change in strength due to heat treatment and comparing the adhesion drop test results after powder bed formation, the material containing silica sand was determined as the most suitable for powder layer 3D printing for application to the mold.
\end{abstract}

Keywords: powder bed 3D printing; alumina cement; molded body; sand casting

\section{Introduction}

The advancements in the casting technology though the 3D printing process satisfies the price competitiveness and improvement in product performance in the sand casting market, thereby rapidly competing with the classic casting method [1]. Functional inorganic materials that can be used at high temperatures, such as castables, using existing cement binders, require high-temperature thermal stability for casting. Mixing cement and foundry sand not only prevents toxic emissions from conventional 3D printing operations, wherein organic and inorganic binders are mainly used, but also simplifies the post-processes [2,3].

The application of 3D printing to sand casting can lead to further innovation in the sand casting resolution as high-temperature compatibility of existing alumina cement and precise shape implementation are steadily investigated through differentiation [4-7]. Sand molds manufactured for casting using traditional casting methods can be easily accessed by applying conventional casting sand [8]. In 3D printing, mold manufacturing, whose resolution can be similar to that of commercial casting sand in the $3 \mathrm{D}$ printing of powder bed, has been commercialized and applied to large castings such as marine engine parts [1,9]. Studies have been conducted to overcome the limitations of shape manufacturing using a finer process to ensure surface resolution and dimensional stability by reducing the material size [10-12]

The resolution of 3D printing is ultimately determined by the uniformity and size (small) of the material, which can reduce the layer height. In recent studies, a uniform 
submicron particle size has been selected through a simple mixing process to solve the agglomeration of ceramic powder $[13,14]$. Alumina, mullite, and fumed silica are commercially used as high-temperature casting sands [15]. Refractory calcium aluminate cement (CAC) exhibits high strength and quick setting at the submicron level [16]. While it is important to ensure sufficient casting mold strength, strength adjustment is required after melting as well to ensure that the mold can be removed and the casting shape can be fully obtained $[8,15]$. Such intensity adjustment has become more necessary owing to the complex shape of the molded body in the increasingly detailed 3D printing market [17]. Additionally, it is essential to remove the mold without damaging the weak and fine parts of the inner cast $[15,18]$.

In this study, the suitability of the handling strength of the mold was confirmed by comparing the formability of sand for casting at the submicron level considering powder bed 3D printing [5]. In order to select a sand with excellent castability and appropriate strength, the strength and phase changes due to heat treatment were checked. Finally, a sessile drop test was performed to verify the applicability of drop test to a powder bed, and the spreadability and strength were compared.

\section{Method and Experiments}

\subsection{Mixed Powder Preparation}

Silica (99\% fused silica, DIGHEN Composite Material Technology Co., Ltd., Lianyungang, China), mullite (fused mullite (64.2 wt $\% \mathrm{Al}_{2} \mathrm{O}_{3}$ and $36.8 \mathrm{wt} \% \mathrm{SiO}_{2}$ ), DIGHEN Composite Material Technology Co., Ltd., Lianyungang, China), and alumina (fused alumina, DIGHEN Composite Material Technology Co., Ltd., Lianyungang, China) powders, which had an average particle size of $4 \mu \mathrm{m}$ (Figure 1), were prepared as the raw sand materials for refractory purposes. The cement used as a binder for preparing the mold was made of CAC (HF80N, UNION Corp., Seoul, Korea) with quick-setting performance powder for fire resistance. The CAC had an average particle size of $<4 \mu \mathrm{m}$ (Figure 1). A water-based activator with $2 \%$ 2-pyrrolidone was used for preparing molded bodies and in powder bed tests. It was dried in a $100{ }^{\circ} \mathrm{C}$ oven for $24 \mathrm{~h}$ to ensure that it could sufficiently mix with the sand to prevent lumping; however, since it contained atmospheric moisture, it was lumpy and not easily mixable. Since the densities of sands were different, as shown in Table 1, the cement was mixed with each sand in a definite volume ratio. The prepared samples were mixed with $1 \mathrm{~mm}$ zirconia medium by horizontal ball milling for $2 \mathrm{~h}$. The cube-shaped mold samples prepared from the mixtures of silica and CAC, mullite and $C A C$, and alumina and $C A C$ were named $S+C, M+C$, and $A+C$, respectively.

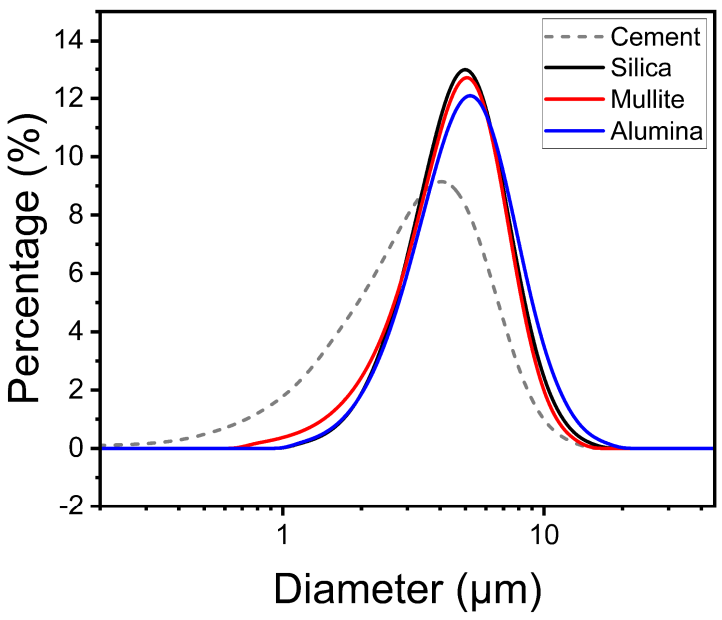

Figure 1. Particle size distribution of component materials. 
Table 1. Density and particle size distribution data of materials.

\begin{tabular}{ccccc}
\hline \multirow{2}{*}{ Components } & Density $(\mathrm{g} / \mathrm{mL})$ & \multicolumn{3}{c}{ Particle Size $(\mu \mathrm{m})$} \\
\cline { 3 - 5 } & & D10 & D50 & D90 \\
\hline CAC & 2.1 & 1.16 & 3.43 & 6.06 \\
$\begin{array}{c}\text { Silica } \\
\text { sand }\end{array}$ & 0.43 & 2.51 & 4.47 & 7.39 \\
$\begin{array}{c}\text { Mullite } \\
\text { sand }\end{array}$ & 1.37 & 2.22 & 4.34 & 7.11 \\
Alumina & & & 4.47 & 7.39 \\
sand & 1.41 & 2.51 & & \\
\hline
\end{tabular}

\subsection{Molded Body Curing}

Each sample mold was prepared with the same cross-sectional area to compare the strength of the unilateral pressure. To fix the size of each molded body, a 200-piece silicone mold, capable of $10 \mathrm{~mm} \times 10 \mathrm{~mm} \times 10 \mathrm{~mm}$ regular hexahedron molding, was prepared (Figure 2). In the powder sample, which was sufficiently mixed with CAC and sand, the activator was poured to hydrate and turn it into a slurry; the amount of activator required for hydrating the CAC was adjusted to ensure a uniform mixture. Previous studies have shown that the change in strength is insignificant when the amount of activator is sufficient. Therefore, the amount of activator was fixed at $40 \%$ to enable sufficient handling [19]. The slurry was sufficiently watery to flow down, and adequate internal air bubbles were removed using a negative pressure device; this slurry was then poured into a silicon frame and shook to prevent pores and ensure uniformity. The dish was then dried at room temperature for $6 \mathrm{~h}$.

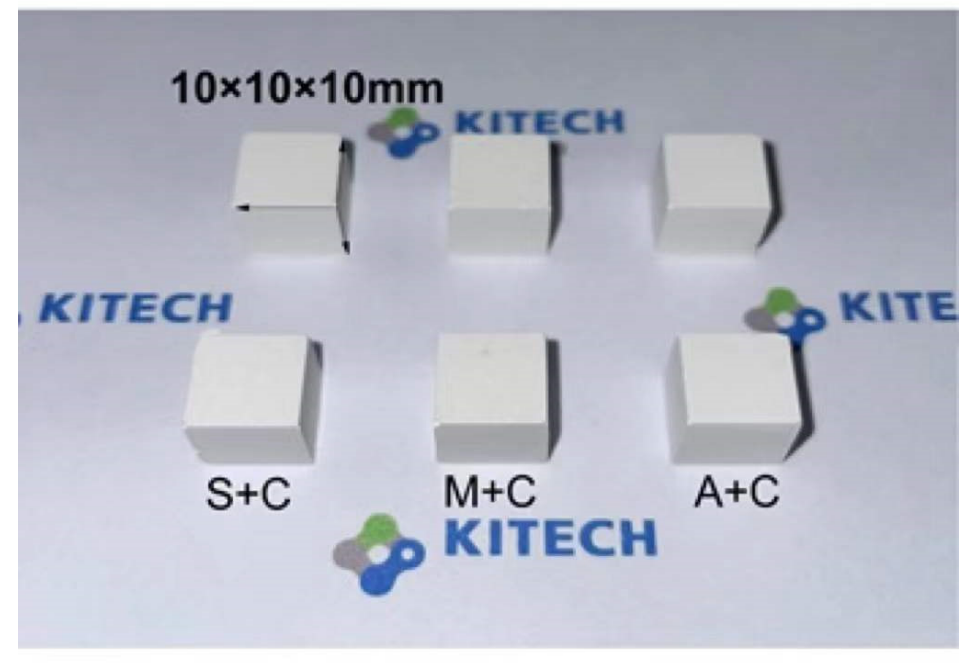

Figure 2. Cube molded bodies made from silicone molds.

\subsection{Sessile Drop Test}

Powder bed recoating was performed using a sessile drop tester (Freeforms T150, SFS, Korea) to determine the powder bed formability. It was intended that the sessile drop tester make use of a layered surface, similar to a powder bed 3D printer. It consisted of a metal frame along the $\mathrm{XY}$ axis and steel rollers with a diameter of $35 \mathrm{~mm}$, connected to a step motor. The axis movement and rotation of the metal roller were controlled using a driver and a speed controller, respectively, and it was installed on a rail without vibration to enable motion at a constant speed along the $\mathrm{X}$ axis. The recoating speed of the recoating device was $50-200 \mathrm{~mm} / \mathrm{s}$, which was fixed for a rotation speed of $20 \mathrm{rpm}$. In order to obtain the same packing density as an actual 3D printer, each powder was recoated to a thickness of $10 \mathrm{~mm}$ on a dense plastic plate. 
The sessile drop test of fixed-size binder droplets on the powder bed surface was performed by pipetting $30 \mu \mathrm{L}$ at a fixed height of $2 \mathrm{~mm}$ (slightly larger than the droplet size to avoid its contact with the powder interface). The droplet was positioned suitably such that the effect of gravity on the droplet was minimized.

\subsection{Characterization}

Avalanche angle testing was performed using the revolution method (revolution powder analyzer, Mercury Scientific Inc., Newtown, CT, USA). In this test, a tap volume of $100 \mathrm{~cm}^{3}$ was measured using a cup, which was filled and tapped until no more powder could be filled in it, and a sharp edge was used to remove the excess powder. The powder was then transferred to a cylindrical drum surrounded by a see-through glass window. The drum was configured to rotate at $0.3 \mathrm{rpm}$ to minimize the effect of surface friction, and the flow behavior of the powder was analyzed using a digital camera. Avalanche angle measurements were averaged on the basis of 125 snapshots, for a total time of $120 \mathrm{~s}$, for reliability. The uniaxial compressive strength was measured using a universal tester (MTS810, Material Test System Corp, Eden Prairie, MN, USA) with a cylindrical sample, which had a diameter, height, and fixed speed of $10 \mathrm{~mm}, 10 \mathrm{~mm}$, and $0.2 \mathrm{~mm} / \mathrm{min}$, respectively. Thermogravimetric (TG) and differential scanning calorimetry (DSC) analyses were performed by heating the samples at $10^{\circ} \mathrm{C} / \mathrm{min}$ in an atmospheric environment using a thermal analyzer (STA449C/3/MFC/G, NETZSCH, Germany). The crystal phase of the 3D-printed template was profiled by X-ray diffraction (XRD, D/max Rigaku 2200V / PC, Japan).

\section{Results and Discussion}

\subsection{Powder Bed Property Evaluation}

In a previous study, the droplet absorption time of the material on the layered surface in powder bed 3D printing was considered as an important parameter in evaluating the recoating possibility [20]. Therefore, in the 3D printing process, it is necessary to optimize the time taken by a droplet to fall on the powder interface and get absorbed [17]. In general commercial 3D printing, when powder is recoated, a new layered surface is formed in $>5 \mathrm{~s}$. Powder bed recoating was performed using a sessile drop tester to determine the absorption time of the activator. Figure 3 a shows the droplet absorption time when the CAC content of each sand is increased in 5\% volume ratio intervals. When the CAC content of every sand is $>20 \%$ of the volume ratio, the droplet absorption time is $<5 \mathrm{~s}$. Figure $3 \mathrm{~b}$ shows the changes in the flowability when the CAC content in each sand is increased in intervals of $5 \%$ by volume in avalanche angle testing. All sands show similar flowability changes depending on the CAC content. A flowability test was performed on each sample powder using the revolution method. The rotation of the drum resulted in the powder being carried along the sides of the drum until the drum could no longer support the powder weight, forming an avalanche. The avalanche angle was measured as the angle at which the powder was at its highest position before the avalanche began. A smaller avalanche angle indicates better flowability of the powder [14]. The standard deviation in the avalanche angle hardly changes up to $20 \%$ CAC content but rapidly increases at a volume ratio of $\geq 25 \%$. Therefore, the experiment was performed at a constant CAC content (20\%), which is smaller than the $25 \%$ cement volume ratio, thereby increasing the flowability variable. 

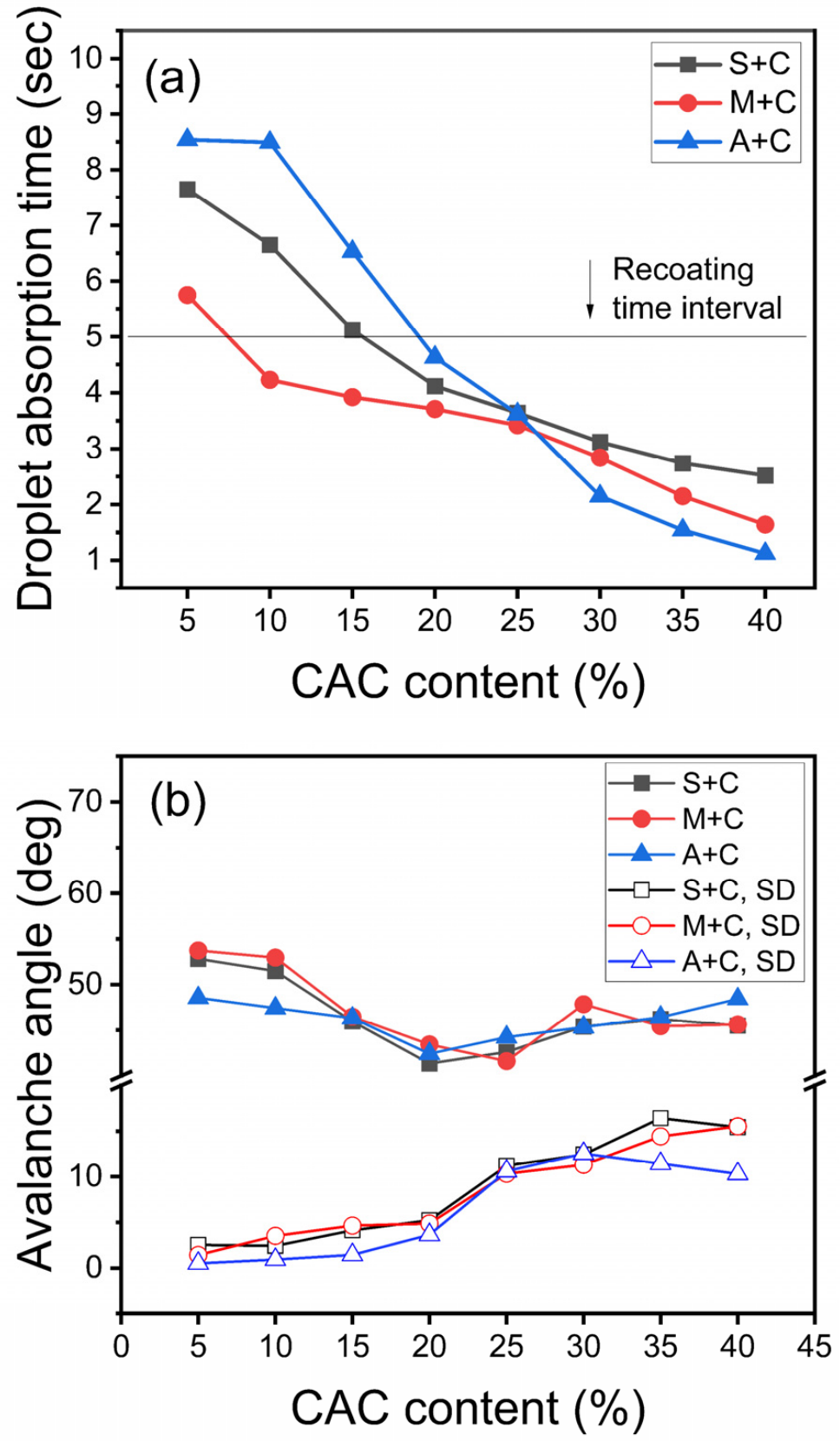

Figure 3. (a) Droplet absorption time and (b) avalanche angle by calcium aluminate cement (CAC) content.

\subsection{Physical Property Evaluation}

The slurry that was poured into the silicone frame via quick binding of CAC completely fell off the frame after $30 \mathrm{~min}$. Subsequently, the uniaxial compressive strength was measured at $1 \mathrm{~h}$ intervals to compare the curing rates (Figure $4 \mathrm{a}$ ). To accurately evaluate the compressive strength, the average value obtained for 20 cube-shaped molded bodies was used for each evaluation. 

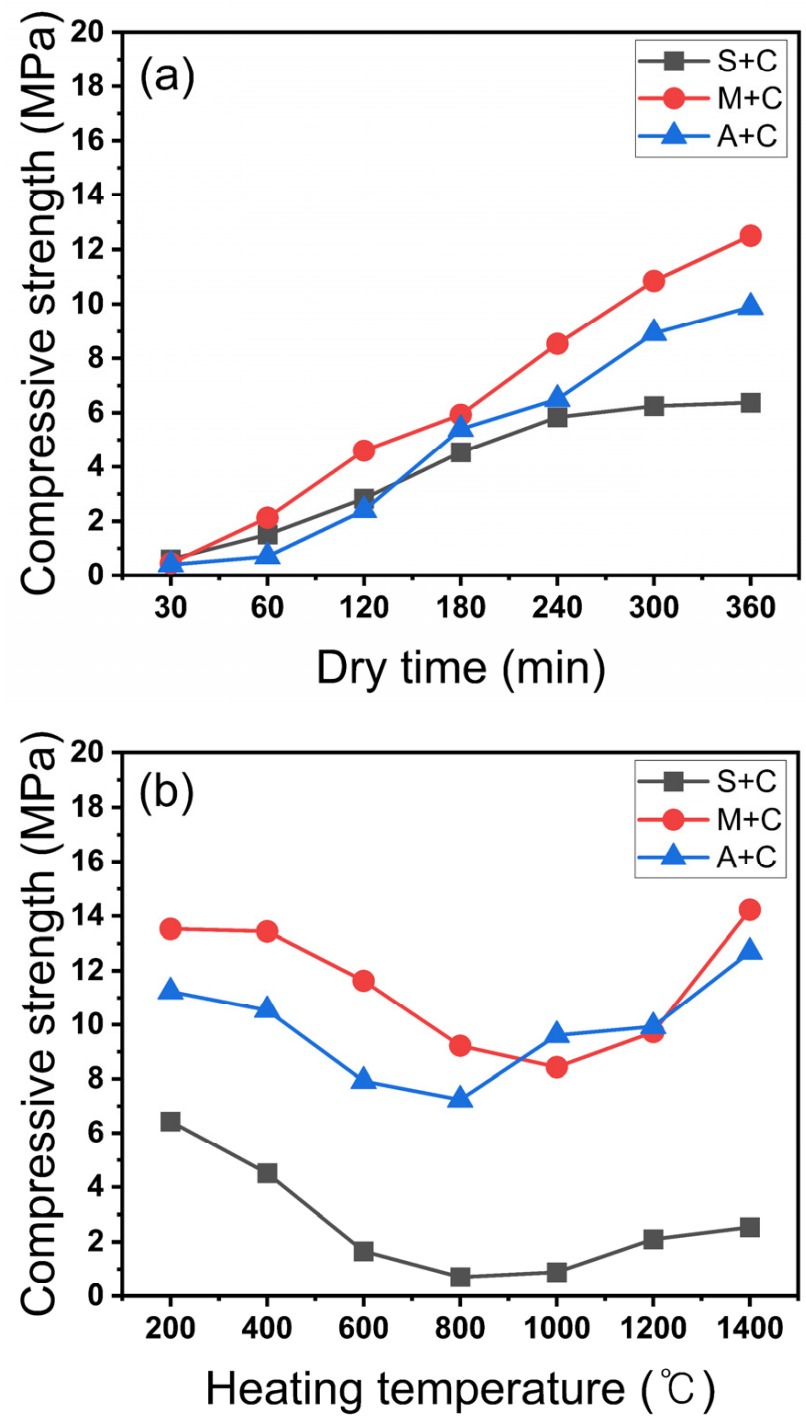

Figure 4. (a) Uniaxial pressing strength by time taken for simple molding, (b) Compressive pressing strength by heat treatment temperature.

As shown in Figure $4 \mathrm{a}$, the $\mathrm{S}+\mathrm{C}$ sample is cured after $4 \mathrm{~h}$ and its strength is $6.02 \mathrm{MPa}$ after $4 \mathrm{~h}$. In contrast, the $\mathrm{M}+\mathrm{C}$ and $\mathrm{A}+\mathrm{C}$ samples are not completely cured after $4 \mathrm{~h}$. The highest strength of the additive-manufactured commercial molds using the same inorganic binder family, a silicate binder, was 2.5-4 $\mathrm{MPa}[10,21]$. In every sample, the handling strength of the mold was satisfied at strengths of $\geq 4 \mathrm{MPa}$ after $4 \mathrm{~h}$ of molding [7,15]. Therefore, a mold that can be treated with a curing time of $4 \mathrm{~h}$ (in powder bed 3D printing) is obtainable for application in rapid molding.

As can be seen in Figure $4 \mathrm{~b}$, all samples are hydrated even after $6 \mathrm{~h}$ of air drying and show slightly higher strengths. All samples show a sharp decrease in strength at $400{ }^{\circ} \mathrm{C}$. Up to their lowest strengths, the $\mathrm{S}+\mathrm{C}, \mathrm{M}+\mathrm{C}$, and $\mathrm{A}+\mathrm{C}$ samples show a reduction in strength of $88.9 \%(6.43 \mathrm{MPa}$ to $0.71 \mathrm{MPa}), 37.7 \%(14.49 \mathrm{MPa}$ to $8.31 \mathrm{MPa})$, and $35.6 \%$ (12.23 MPa to 7.23 MPa), respectively. This affects the characteristics of CAC owing to the different sand types; CAC cement showed the same trend as a result of strength reduction in the temperature range $600-1200{ }^{\circ} \mathrm{C}$ [16,22-24]. In comparison, the strength of silica significantly decreased at $600{ }^{\circ} \mathrm{C}$, and the strength recovery was slow at higher heating temperatures [22]. On the other hand, alumina rapidly recovered its strength after the lowest strength at $800{ }^{\circ} \mathrm{C}$, whereas mullite showed a decrease in strength after the recovery at $1000{ }^{\circ} \mathrm{C}$. This is a result of the change in pores due to sintering [25-27]. 


\subsection{Thermal Property Evaluation}

The initial strength of CAC cement is the formation of hexagonal hydrates $\left(\mathrm{CAH}_{10}\right.$ and $\mathrm{C}_{2} \mathrm{AH}_{8}$ ) as the main hydration products [27]. However, $\mathrm{CAH}_{10}$ and $\mathrm{C}_{2} \mathrm{AH}_{8}$ are metastable and are known to get converted to the more stable $\mathrm{C}_{3} \mathrm{AH}_{6}$ and $\mathrm{AH}_{3}$ species. In Figure 5a, every sample shows an $\mathrm{AH}_{3}$ conversion endothermic signal at $240{ }^{\circ} \mathrm{C}[28,29]$. Additionally, all samples exhibit an inflection point with varying strengths near $800^{\circ} \mathrm{C}$. The DSC profile of the $\mathrm{S}+\mathrm{C}$ sample showed that siliceous sand sintering occurs at approximately $1250{ }^{\circ} \mathrm{C}$, resulting in a strong bond between the sand, but the strength of the actual mold body does not significantly increase. Therefore, the cristobalite formation apparently dominates the crystallization of sand $[30,31]$. The $M+C$ and $S+C$ samples have similar peaks owing to sintering above $1200{ }^{\circ} \mathrm{C}[25,32]$. However, in the $\mathrm{A}+\mathrm{C}$ sample, the peak is sintered near $1350{ }^{\circ} \mathrm{C}$ [32]. These results support the increase in strength observed at heat treatment above $1000{ }^{\circ} \mathrm{C}$.
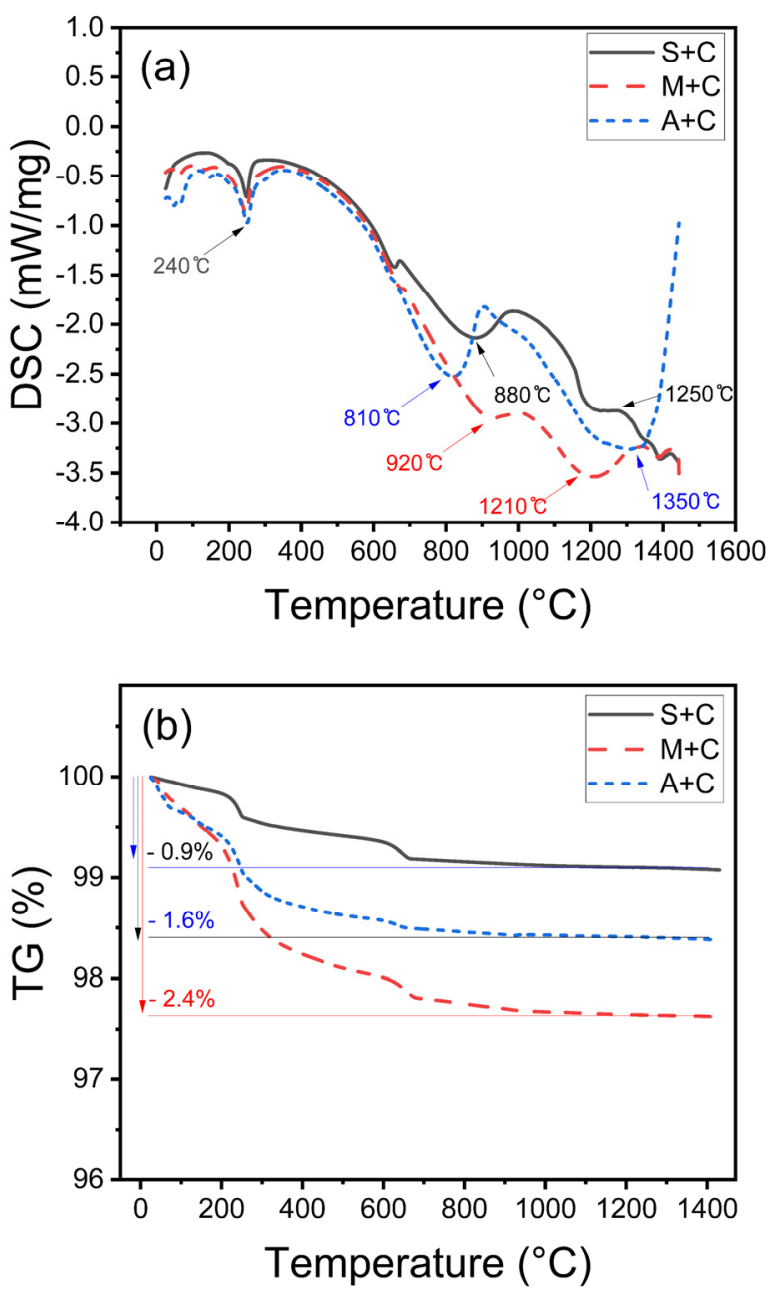

Figure 5. (a) DSC profiles of molded body, (b) TG profiles of molded body.

Figure $5 \mathrm{~b}$ compares the reduction in mass according to temperature change. Because the CAC content was different in volume ratio for each prepared sample, the amount of hydration was expected to be different. The CAC content was measured by hydrating the sand, in which $20 \mathrm{wt} \%$ was added in mass ratios in the same manner as the $\mathrm{S}+\mathrm{C}, \mathrm{M}+\mathrm{C}$, and $\mathrm{A}+\mathrm{C}$ samples. Assuming that the rapid gas generation is caused by the molten metal during the casting process, the speed of generation of the initial gas and the amount of generated gas affects the casting defects [27]. The $S+C$ sample exhibits a relatively small mass decrease of $0.9 \%$. In contrast, in the $\mathrm{A}+\mathrm{C}$ sample, the mass decrease is $1.6 \%$ up to $1200{ }^{\circ} \mathrm{C}$, and the $\mathrm{M}+\mathrm{C}$ sample shows a mass decrease of $2.4 \%$. For the $\mathrm{S}+\mathrm{C}$ and $\mathrm{A}+\mathrm{C}$ 
samples, the mass loss upon heating the mold using molten cast iron is $\leq 1.6 \%$, the level that is encountered in commercial foundry sand [33]. This reduction in mass is proportional to the amount of gas generated during casting. Therefore, the smaller the generation of gas, the more suitable the mold material is for casting. In addition, the mass reduction velocity can also predict the slowest gas generation process in the case of the $\mathrm{S}+\mathrm{C}$ sample.

To confirm that the strength trends for each type of sand by high-temperature heat treatment are different, we attempted to identify the phase changes on the surface of molds as the temperature dropped to $1400{ }^{\circ} \mathrm{C}$ or less, assuming that the steel was cooled after initial molding for each sample and the temperature of molten metal is approximately $1400{ }^{\circ} \mathrm{C}$. Therefore, the phases after $30 \mathrm{~min}$ of heat treatment at $1400{ }^{\circ} \mathrm{C}$ were compared.

Figure 6 shows the XRD pattern of the $S+C$ sample. The $C_{2} A_{3}$ and $C_{4} A_{1} H_{19}$ phases, which are hydrated by the CAC observed at $200{ }^{\circ} \mathrm{C}$, confirm that the peaks weaken owing to dehydration at $1400{ }^{\circ} \mathrm{C}$. The existing amorphous silica crystallizes at $1400{ }^{\circ} \mathrm{C}$, which promotes the cristobalite phase formation [34,35]. Cristobalite reduces the hardening strength of the mold, thereby affecting the low sintering strength shown in Figure $4 \mathrm{~b}$.

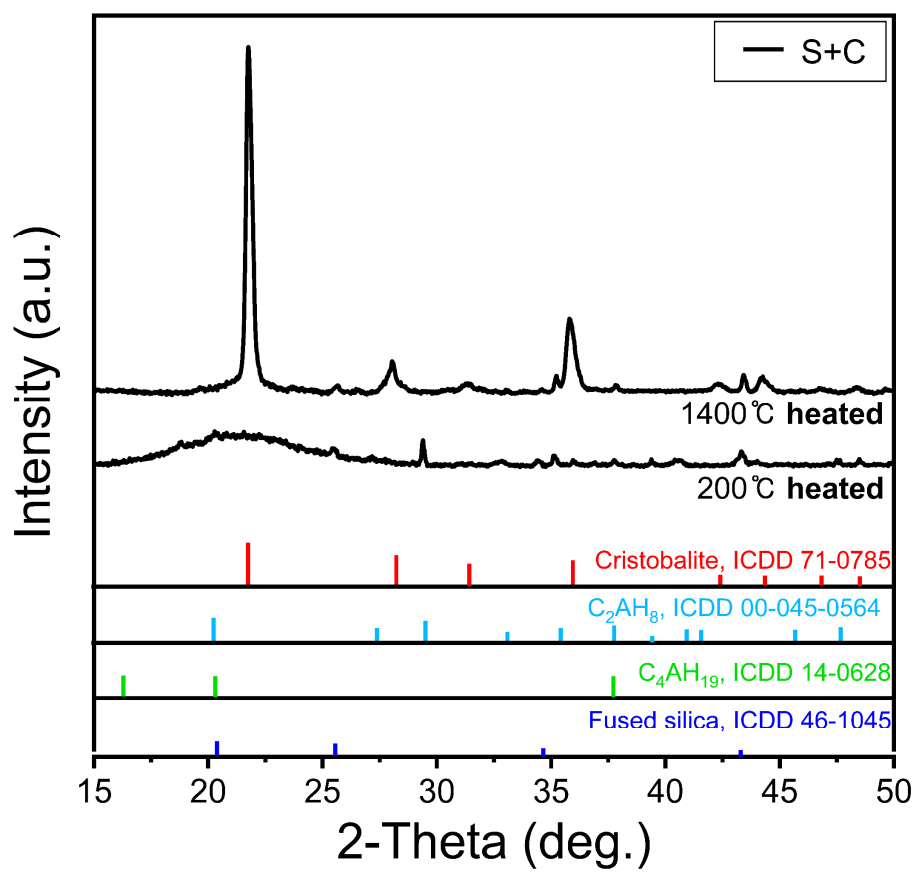

Figure 6. XRD peaks after heat treatment at $200{ }^{\circ} \mathrm{C}$ and $1400{ }^{\circ} \mathrm{C}$ of silica sand and CAC mixed molded body.

Figure 7 shows the XRD pattern of the $M+C$ sample. The molded body dried at $200{ }^{\circ} \mathrm{C}$ is sufficiently hydrated and shows no $\mathrm{CA}, \mathrm{CA}_{2}$, and $\mathrm{CA}_{6}$ component peaks, which are the $\mathrm{CAC}$ phases. The $\mathrm{C}_{2} \mathrm{AH}_{8}$ and $\mathrm{C}_{2} \mathrm{AH}_{19}$ peaks that appear after the initial hydration disappear or weaken at $1400{ }^{\circ} \mathrm{C}$. The mullite phases, shown at $200{ }^{\circ} \mathrm{C}$, transform to corundum and cordoerite phases when heated to $1400{ }^{\circ} \mathrm{C}$. Then, the formation of corundum appears to affect the reduction in strength of the molded body [26]. However, at $1400^{\circ} \mathrm{C}$, the cordoerite phases are identified more prominently, thus confirming an increase in strength due to the sintering of mullite up to $1400{ }^{\circ} \mathrm{C}$ [27]. 


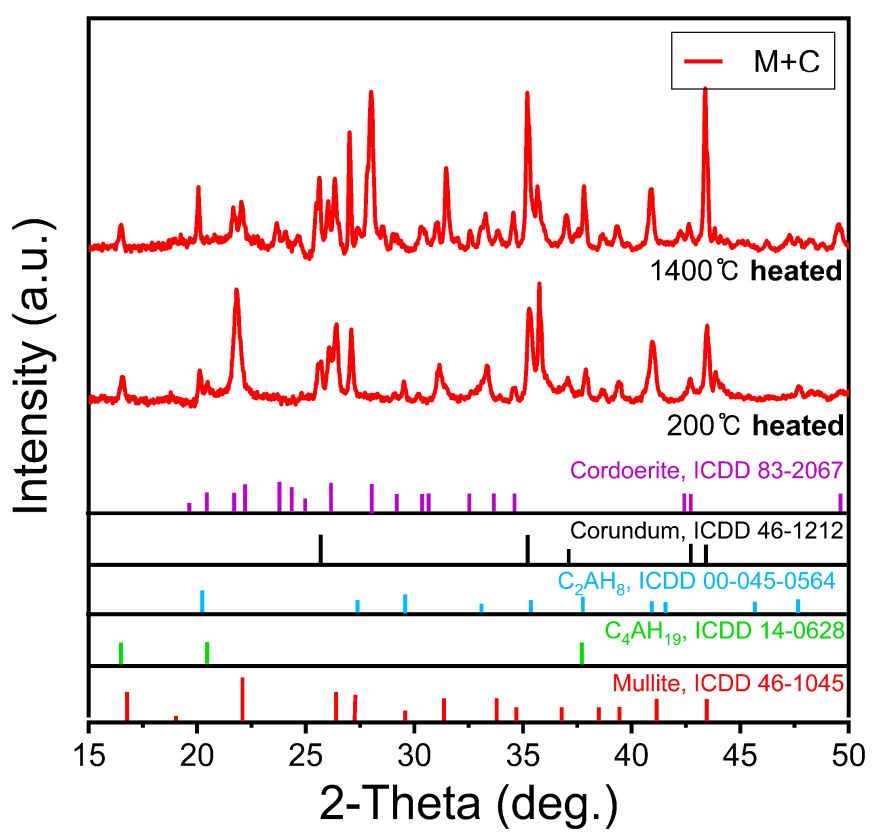

Figure 7. XRD peaks after heat treatment at $200{ }^{\circ} \mathrm{C}$ and $1400{ }^{\circ} \mathrm{C}$ of mullite sand and CAC mixed molded body.

Figure 8 depicts the XRD pattern of the $\mathrm{A}+\mathrm{C}$ sample. Similar to the $\mathrm{M}+\mathrm{C}$ sample, the $\mathrm{C}_{2} \mathrm{AH}_{8}$ and $\mathrm{C}_{2} \mathrm{AH}_{19}$ peaks that appear after the initial hydration disappear or weaken at $1400{ }^{\circ} \mathrm{C}$. Owing to the compositional characteristics of the initial CAC, no evident crystal phase change is observed as a consequence of the increase in the existing alumina component. However, the $\mathrm{CA}, \mathrm{CA}_{2}$, and $\mathrm{CA}_{6}$ components are indeed revived because $\mathrm{CAC}$ dehydrates at high temperatures. This seems to be a minor change that does not affect the strength increase caused by the sintering of alumina. In addition, the peaks of $\mathrm{C}_{2} \mathrm{AH}_{8}$ and $\mathrm{C}_{2} \mathrm{AH}_{19}$ that appear after the initial hydration disappear or weaken at $1400^{\circ} \mathrm{C}$, indicating sufficient dehydration due to high-temperature heat treatment [22,36-38].

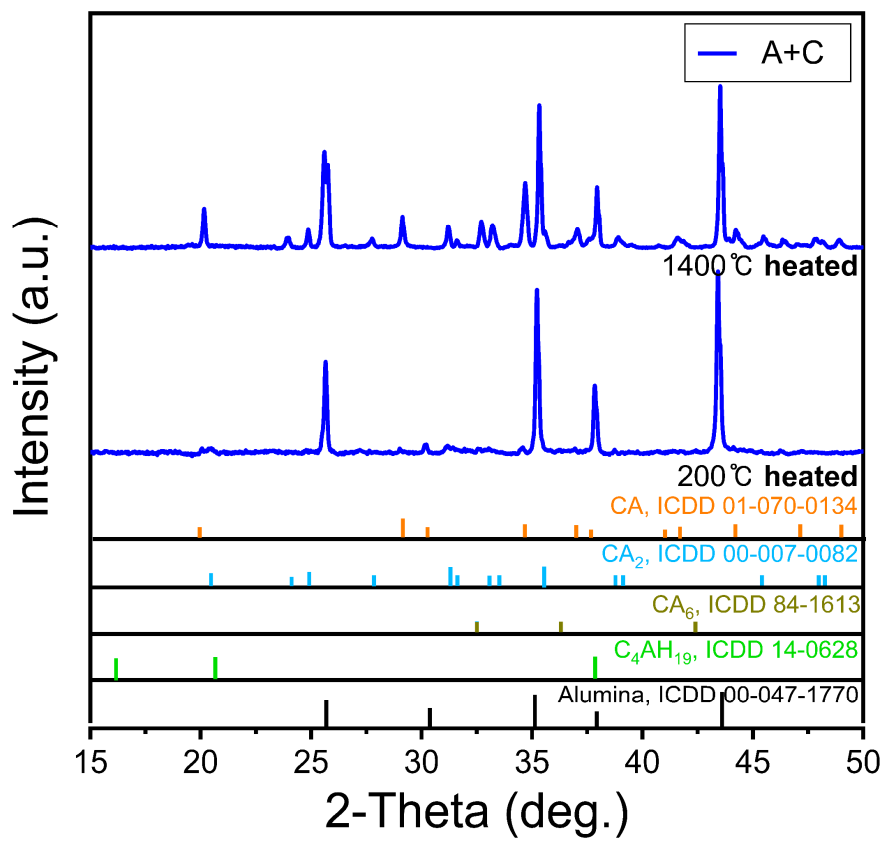

Figure 8. XRD peaks after heat treatment at $200^{\circ} \mathrm{C}$ and $1400{ }^{\circ} \mathrm{C}$ of alumina sand and $\mathrm{CAC}$ mixed molded body. 
Every mixed powder sample for 3D printing was investigated by preparing a powder bed using a sessile drop tester (Figure 9a). Figure $9 \mathrm{~b}$ shows the absorption area of the droplets formed at the powder interface in terms of the spread diameter. In addition, every absorbed region was separated from the powder bed after $4 \mathrm{~h}$ to measure the compressive strength. The average spread diameters of the $S+C, M+C$, and $A+C$ samples are $7.4 \mathrm{~mm}$ (narrowest), $9.2 \mathrm{~mm}$, and $8.3 \mathrm{~mm}$, respectively. An inference from the spread diameters of the droplet is that the surface resolution of the molded body is adversely affected when the mold shows high spread diameters [17]. Therefore, the surface quality of the $S+C$ sample is expected to be better. In Figure 9c, the strength values show the same trend as the strength results measured on the molded body, i.e., a lower strength despite the same $4 \mathrm{~h}$ curing time. It is only that the formation of forming strength after the hydration process by water drop is lower than the water reactivity by slurrying [5].

(a)
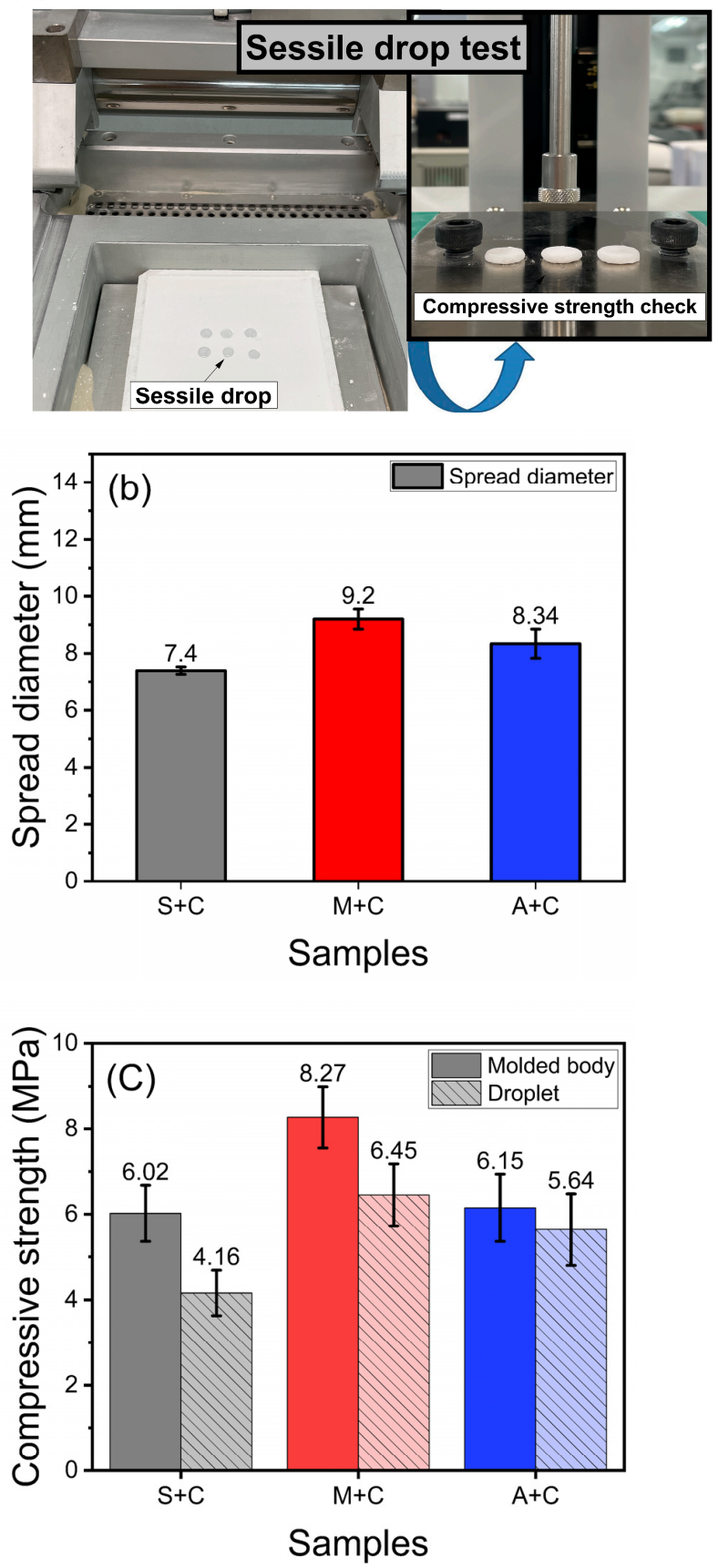

Figure 9. Powder bed sessile drop test: (a) Proceed with sessile drop test using sessile drop tester, (b) spread diameter as a result of sessile drop test, (c) compressive strength as a result of sessile drop test. 


\section{Conclusions}

A fine powder casting usable for powder bed 3D printing, in which CAC was mixed, was manufactured by varying the sand used for sand casting. Droplet absorption time and flowability were optimized at $20 \%$ cement volume ratio of CAC cement for each sand. The hydration strength, from which the initial handling strength of the mold can be predicted, was determined to be sufficient within $4 \mathrm{~h}$ between $2.5 \mathrm{MPa}$ and $4 \mathrm{MPa}$, which is the pressure range of commercial inorganic binders. The temperature range for de-powdering was confirmed to be $600-1200{ }^{\circ} \mathrm{C}$ by the phase change in each sample, and the defect reduction characteristic of $\mathrm{CAC}$ due to the heat applied during the melting process was evident in the $\mathrm{S}+\mathrm{C}$ sample. The proportion of the gas generated by the thermal reaction was small, which was considered suitable for molding sand $(0.9 \%)$. The $\mathrm{S}+\mathrm{C}$ sample formed the best powder interface in terms of spread diameter, as confirmed by the sessile drop tester. In conclusion, the $\mathrm{S}+\mathrm{C}$ mixed casting sand is highly suitable as a molding material for casting via powder bed 3D printing.

Author Contributions: Conceptualization, S.C.; methodology, G.L., S.K., B.J. and J.S.; validation, H.K. and H.L.; formal analysis, T.K.; investigation, H.K.; resources, H.K. and I.C.; writing-original draft preparation, S.C. and T.K.; writing-review and editing, S.C. and T.K.; visualization, G.L.; supervision, H.L.; project administration, H.K.; funding acquisition, H.K. All authors have read and agreed to the published version of the manuscript.

Funding: This work was supported by Korea Ministry of Trade Industry and Energy (Grant number: \#10067386), Korea Ministry of Science and ICT (Grant number: EO200014), and the Ministry of Environment (grant number: 2020003060014).

Institutional Review Board Statement: Not applicable.

Informed Consent Statement: Not applicable.

Data Availability Statement: All data are presented in this article in the form of figures and tables.

Acknowledgments: We acknowledge the financial support from the Ministry of Trade, Industry and Energy, South Korea (MOTIE, grant number: \#10067386), the Ministry of Science and ICT, South Korea (MSIT, grant number: EO200014), and the Ministry of Environment (grant number: 2020003060014).

Conflicts of Interest: The authors declare no conflict of interest.

\section{References}

1. Yilmaz, O.; Anctil, A.; Karanfil, T. LCA as a decision support tool for evaluation of best available techniques (BATs) for cleaner production of iron casting. J. Clean. Prod. 2015, 105, 337-347. [CrossRef]

2. Saloum, Q.A.; Abdullah, M.Z.; Hashim, A.A. The preparation of foam cement and determining some of its properties. Eng. Technol. J. 2015, 33, 61-69.

3. Hodder, K.J.; Chalaturnyk, R.J. Bridging additive manufacturing and sand casting: Utilizing foundry sand. Addit. Manuf. 2019, 28, 649-660. [CrossRef]

4. Lowke, D.; Dini, E.; Perrot, A.; Weger, D.; Gehlen, C.; Dillenburger, B. Particle-bed 3D printing in concrete constructionPossibilities and challenges. Cem. Concr. Res. 2018, 112, 50-65. [CrossRef]

5. Pshtiwan, S.; Shami, N.; Gavin, P. An Investigation into the Effects of Deposition Orientation of Material on the Mechanical Behaviours of the Cementitious Powder and Gypsum Powder in Inkjet 3D Printing. In Proceedings of the 36th International Symposium on Automation and Robotics in Construction (ISARC), Banff, AB, Canada, 21-24 May 2019.

6. Gibbons, G.; Williams, R.; Purnell, P.; Farahi, E. 3D Printing of cement composites. Adv. Appl. Ceram. 2010, 109, 287-290. [CrossRef]

7. Huang, S.; Ye, C.; Zhao, H.; Fan, Z. Additive manufacturing of thin alumina ceramic cores using binder-jetting. Addit. Manuf. 2019, 29, 100802. [CrossRef]

8. Zheng, J.; Chen, A.; Zheng, W.; Zhou, X.; Bai, B.; Wu, J.; Ling, W.; Ma, H.; Wang, W. Effectiveness analysis of resources consumption, environmental impact and production efficiency in traditional manufacturing using new technologies: Case from sand casting. Energy Convers. Manag. 2020, 209, 112671. [CrossRef]

9. Anwar, N.; Sappinen, T.; Jalava, K.; Orkas, J. Comparative experimental study of sand and binder for flowability and casting mold quality. Adv. Powder Technol. 2021, 32, 1902-1910. [CrossRef]

10. Upadhyay, M.; Sivarupan, T.; El Mansori, M. 3D printing for rapid sand casting-A review. J. Manuf. Process. 2017, 29, 211-220. [CrossRef] 
11. Miyanaji, H.; Rahman, K.M.; Da, M.; Williams, C.B. Effect of fine powder particles on quality of binder jetting parts. Addit. Manuf. 2020, 36, 101587. [CrossRef]

12. Zhang, J.; Amini, N.; Morton, D.A.; Hapgood, K.P. Binder jetting of well-controlled powder agglomerates for breakage studies Adv. Powder Technol. 2020, 32, 19-29. [CrossRef]

13. Mussatto, A.; Groarke, R.; O’Neill, A.; Obeidi, M.A.; Delaure, Y.; Brabazon, D. Influences of powder morphology and spreading parameters on the powder bed topography uniformity in powder bed fusion metal additive manufacturing. Addit. Manuf. 2020, 38, 101807. [CrossRef]

14. Alexander, A.W.; Chaudhuri, B.; Faqih, A.; Muzzio, F.J.; Davies, C.; Tomassone, M.S. Avalanching flow of cohesive powders Powder Technol. 2006, 164, 13-21. [CrossRef]

15. Sivarupan, T.; Balasubramani, N.; Saxena, P.; Nagarajan, D.; El Mansori, M.; Salonitis, K.; Jolly, M.; Dargusch, M.S. A review on the progress and challenges of binder jet 3D printing of sand moulds for advanced casting. Addit. Manuf. 2021, 40, 101889. [CrossRef]

16. Simonin, F.; Olagnon, C.; Maximilien, S.; Fantozzi, G.; Diaz, L.A.; Torrecillas, R. Thermomechanical Behavior of High-Alumina Refractory Castables with Synthetic Spinel Additions. J. Am. Ceram. Soc. 2004, 83, 2481-2490. [CrossRef]

17. Lv, X.; Ye, F.; Cheng, L.; Fan, S.; Liu, Y. Binder jetting of ceramics: Powders, binders, printing parameters, equipment, and post-treatment. Ceram. Int. 2019, 45, 12609-12624. [CrossRef]

18. Kang, J.; Shangguan, H.; Deng, C.; Hu, Y.; Yi, J.; Wang, X.; Zhang, X.; Huang, T. Additive manufacturing-driven mold design for castings. Addit. Manuf. 2018, 22, 472-478. [CrossRef]

19. Shakor, P.; Sanjayan, J.; Nazari, A.; Nejadi, S. Modified 3D printed powder to cement-based material and mechanical properties of cement scaffold used in 3D printing. Constr. Build. Mater. 2017, 138, 398-409. [CrossRef]

20. Chun, S.-Y.; Kim, T.; Ye, B.; Jeong, B.; Lee, M.-J.; Lee, D.H.; Kim, E.-S.; Lee, H.; Kim, H.-D. Capillary pressure and saturation of pore-controlled granules for powder bed binder jetting. Appl. Surf. Sci. 2020, 515, 145979. [CrossRef]

21. ExOne GmbH. X1_Handout_Inorganic_Binder. Available online: https://www.exone.com/Admin/ExOne/media/SandBinders/210310_X1_Handout_Inorganic_Binder_EN_2021-03_www.pdf (accessed on 10 March 2021).

22. Black, L.; Breen, C.; Yarwood, J.; Deng, C.-S.; Phipps, J.; Maitland, G. Hydration of tricalcium aluminate $\left(C_{3} A\right)$ in the presence and absence of gypsum - studied by Raman spectroscopy and X-ray diffraction. J. Mater. Chem. 2006, 16, 1263-1272. [CrossRef]

23. Sing, S.L.; Yeong, W.Y.; Wiria, F.E. Selective laser melting of titanium alloy with $50 \mathrm{wt} \%$ tantalum: Microstructure and mechanical properties. J. Alloys Compd. 2016, 660, 461-470. [CrossRef]

24. Kumar, V.; Singh, V.K.; Srivastava, A.; Kumar, P.H. Mechanochemically synthesized high alumina cement and their implementation as low cement castables with some micro-fine additives. J. Asian Ceram. Soc. 2015, 3, 92-102. [CrossRef]

25. Pratapa, S.; Wahyuni, T.; Fauziyah, N.A.; Apriliyana, G.A.; Mashuri, M.; Firdaus, S. Synthesis and thermomechanical characterization of PEG/cristobalite composites. J. Mech. Sci. Technol. 2017, 31, 3653-3656. [CrossRef]

26. Zhang, S.; Tie, S.; Zhang, F. Cristobalite formation from the thermal treatment of amorphous silica fume recovered from the metallurgical silicon industry. Micro Nano Lett. 2018, 13, 1465-1468. [CrossRef]

27. Saltzberg, M.A.; Bors, S.L.; Bergna, H.; Winchester, S.C. Synthesis of Chemically Stabilized Cristobalite. J. Am. Ceram. Soc. 1992, 75, 89-95. [CrossRef]

28. Mostafa, N.Y.; Zaki, Z.; Elkader, O.H.A. Chemical activation of calcium aluminate cement composites cured at elevated temperature. Cem. Concr. Compos. 2012, 34, 1187-1193. [CrossRef]

29. Wang, F.; Xiangcheng, L.; Li, X.; Zhu, B. Effect of Colloidal Silica on the Hydration Behavior of Calcium Aluminate Cement. Materials 2018, 11, 1849. [CrossRef]

30. Lin, Q.; Zhao, N.; Yao, K.; Jiang, Z.; Tian, B.; Shi, P.; Chen, F. Ordinary Optical Fiber Sensor for Ultra-High Temperature Measurement Based on Infrared Radiation. Sensors 2018, 18, 4071. [CrossRef] [PubMed]

31. Richet, P.; Bottinga, Y.; Denielou, L.; Petitet, J.; Tequi, C. Thermodynamic properties of quartz, cristobalite and amorphous $\mathrm{SiO}_{2}$ : Drop calorimetry measurements between 1000 and $1800 \mathrm{~K}$ and a review from 0 to $2000 \mathrm{~K}$. Geochim. Cosmochim. Acta 1982, 46, 2639-2658. [CrossRef]

32. Hapgood, K.P.; Litster, J.D.; Biggs, S.; Howes, T. Drop Penetration into Porous Powder Beds. J. Colloid Interface Sci. 2002, 253, 353-366. [CrossRef]

33. Snelling, D.; Williams, C.; Druschitz, A. A comparison of binder burnout and mechanical characteristics of printed and chemically bonded sand molds. In Proceedings of the SFF Symposium, Austin, TX, USA, 4-6 August 2014

34. Zhang, Z.; Zhou, W.; Han, B.; Li, Y.; Yan, W.; Xu, N.; Li, N.; Wei, J. Preparation and characterization of eco-friendly and low-cost mullite-corundum foamed ceramics with low thermal conductivity. Ceram. Int. 2019, 45, 13203-13209. [CrossRef]

35. Yan, W.; Luo, H.; Tong, J.; Li, N. Effects of sintering temperature on pore characterization and strength of porous cordierite-mullite ceramics by a pore-forming in-situ technique. Int. J. Mater. Res. 2012, 103, 1239-1243. [CrossRef]

36. Wang, Y.; Li, X.; Zhu, B.; Chen, P. Microstructure evolution during the heating process and its effect on the elastic properties of CAC-bonded alumina castables. Ceram. Int. 2016, 42, 11355-11362. [CrossRef]

37. Ukrainczyk, N.; Matusinovic, T.; Kurajica, S.; Zimmermann, B.; Sipusic, J. Dehydration of a layered double hydroxide-C2AH8 Thermochim. Acta 2007, 464, 7-15. [CrossRef]

38. Yum, W.S.; Suh, J.-I.; Kim, D.H.; Oh, J.E. Prevention of potential strength degradation due to conversion of $\mathrm{C}_{2} \mathrm{AH}_{8}$ formed in $\mathrm{CaO}-\mathrm{Ca}(\mathrm{HCOO})_{2}$-activated GGBFS binder using $\mathrm{CaSO}_{4}$. Constr. Build. Mater. 2020, 253, 119186. [CrossRef] 